\title{
Trade Agreement and Diplomacy between Tunisia and Indonesia
}

\author{
Akbar Azmi \\ Graduate of Department of International Relations, Syarif Hidayatullah State Islamic University Jakarta \\ akbar.azmi20@gmail.com
}

\begin{abstract}
After two decades of the reform era, Indonesia developed its influence and power as far as the Middle East by assisting and having a mutual partnership with some countries of the Middle East in economic and democratic transition, including Tunisia. Tunisia is one of the sub-Saharan nations affected by the Arab Spring from December 2010. Tunisia attempted to transform democratic change by strengthening economy and development and initiated to make a partnership with Asian countries such as Indonesia in tourism and energy sectors. The Indonesian multi-national company has become a partner in the Tunisian government. The article will analyze how Indonesian companies can manage a diplomacy tool in making cooperation with the Tunisian government. It also answers the question of why Indonesia is the right partner of Tunisia after the restoration of Arab Spring. It will combine in-depth interviews with multinational companies in Indonesia which have taken an agreement with Tunisia, and the Indonesian and Tunisian government report on the economic partnership between two countries.
\end{abstract}

Keyword - Trade Agreement, Economic Cooperation, Tunisia, Indonesia

\section{INTRODUCTION}

Arab Spring is a series of anti-government uprisings in various countries in North Africa and the Middle East, beginning in Tunisia in December 2010. Tunisia is experiencing a turbulent revolution (Arab Spring) and has become a role model country to other countries to do the same action. Egypt and Syria became the next countries affected by the Arab Spring. However, Tunisia which is now in Post-Arab Spring and has experienced many changes in internal state or more precisely in the system of the general election, the party and the mass media in the country, which also have a quite impact on the economy which is quite progressive.

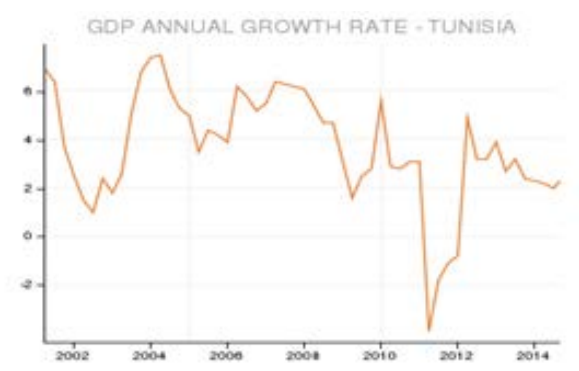

Figure. I Tunisia's GDP Annual Growth Rate 20022014.
In the graph, we can see the clarity of the level of post-drop Arab Spring and post-Arab Spring. The condition of the economy come back to normal and become a reference for the Tunisian in establishing the cooperation that may bring the economic benefits[1].

It is the opportunity to be taken by Indonesia in striving for the maximum economy with the existence of the same significant improvements from the Tunisian authorities to restore the condition of the country. Indonesia is expected to maximize the opportunity to prosper society with a Trade Agreement that became the beginning of the cooperation.

More than half of Tunisia is covered by forests of rural land used for agriculture, supporting plants such as olives and dates, oranges, almonds, nuts, sugar bit, wine, poultry, meat, and milk. The main benefit is derived from the industry such as mining phosphate, iron ore, the oil industry and textiles from Tunisia.

\section{ECONOMIC OPPORTUNITIES BETWEEN TUNISIA AND INDONESIA AFTER ARAB SPRING.}

According to Susan, changes in the structure to become a liberal system will cause U-turn on specific sectors, i.e.:

a) Technological Change, mobile capital, cross-border communication, and

b) A broader perspective [2]

It is the situation in Tunisia at the moment after the Arab Spring. The situation is almost the same with the root of the structural changes in the state of the Soviet Union, Europe and Meiji restoration in Japan.

Tunisia mostly establishes its investments in the coastal areas that are well equipped with public services and infrastructure. It gives them investors that bring a bigger opportunity for economic growth. Meanwhile, the inland area lost investment. Hence, having a higher level of unemployment and poverty [3]. 
Unemployment is so high; however, in fact, it is another factor that can contribute to the revolution to get more attention at about 13 percent year-onyear later. Right before the revolution, Tunisia had about 600 thousand unemployment including 200 thousand diploma graduates. Demographics population highly drives the level of unemployment. Young people grow faster than the economy. It is estimated that Tunisia will need the level of economic growth of 7 to 8 percent per year to overcome all the new job seekers [3].

An analysis of economic sector growth in Tunisia in 2013 showed a 3.3 percent per in the field of agriculture and fisheries sectors, following a sharp drop in the production of cereals. The nonmanufacturing industry also experienced falls in their value-add ( 0.4 percent), because of the decrease of energy production (3.2 percent), especially oil and natural gas extraction (3.8\%). In 2014, the main priority of Tunisia was to gather funds to implement development and the work of the program. The budget also highlighted the need to support economic activity, foster investment and continuity to provide grants to the production of necessities and services, especially energy and transportation [4].

In 2014, Tunisia and Indonesia agreed to increase economic cooperation. However, Indonesia was still waiting for the legal provision after the governmental transition of countries in North Africa. Countries that were experiencing the revolution in 2011 were in the process of democratic presidential election. According to the data from the Ministry of Trade in Indonesia, Indonesian trade to Tunisia in 2013 reached 101.9 million US dollars. The value of Indonesian exports reached 75.9 million US dollars with the import was around 26.1 million US dollars. It means Indonesia enjoyed the surplus of 69.1 million US dollars [5].

It is why Indonesia must form a strategy of cooperation with Tunisia to help to support the economy of the country. It is not difficult to build diplomacy with the Tunisia. In the process of the development, Tunisia probably also requires a renewable energy development as well as in the transportation and agriculture sectors that received less attention from Tunisian government.

Indonesia is rich in the agricultural sector that can be a bargaining position strategy in the formation of the trade agreement in the long term. This opportunity will be the process of Tunisian relations with Indonesia which the deal was valid in 2014. Indonesia also requires an action in friendship in the development of the transitional situation in Tunisia, not only when the transition is complete. It can make the stigma of good relations with Tunisia after the Arab Spring is completed.

Indonesia's opportunity became significant when a corporation named MNC from Indonesia (PT Medco) shows its dramatic development in Tunisia. The other companies in Indonesia are also expected to establish the deal in trading or cooperation in the economic and investment [6].

\section{FIRMS DIPLOMACY AS DIPLOMACY AND COOPERATION INSTRUMENT BETWEEN TUNISIA AND INDONESIA}

Susan Strange theory also spoke about how diplomacy or international relations have already started to evolve even in two ways:

\section{a) State-Firm Diplomacy}

\section{b) Firm-Firm Diplomacy}

It gives the opportunity for Indonesia in starting a good cooperation with Tunisia in structural change as a result of the Arab Spring. The firm relationship according to Susan is the impact of the structural changes in Tunisia after the massive revolution called the Arab Spring. Tunisia will also become a point of reference for Indonesia in addressing a major opportunity to cooperate with Tunisia in trade and investment into that country.

Large companies owned by Hilmi Panigoro from Indonesia (PT Medco Energy) can develop rapidly in the land of Morocco until now. The company has developed and work well with the domestic companies in Tunisia [7].

Meanwhile, after Arab Spring, the technology changes becomes a new process for Tunisia, then become a reference for Tunisia changing the orientation of the country's land development. The technology will be faster absorbed by Indonesia because of the natural resources, geographic factors, and also other factors that support the history of Tunisia in the innovation development of technology. The preparation of Tunisia's internal development will become an excellent response in creating a cooperation partnership with Indonesia. Indonesia which is a developing country (take off vertically) also has the opportunity toward this prosperous land.

First of all, the formation of such cooperation will be more readily if we see the domestic condition of Tunisia. Structural changes have been seeping out of the finance and production sectors which affect global politics on a deep level. They, for example, significantly affect the North-South relationship. It is predicted that the Third World 
countries like Tunisia will no longer build a coalition with developing countries, which according to UNCTAD (UN Conference on Trade and Development), are in contrary to the rich countries. Developing countries are now aware that they are competing, slowly but hard to keep pace in forming new successful industrial countries [8].

The change to a wider view will also make Tunisia as a country that has a strong potential to be sustained as the spear of world trade. In short, people become better and more educated that creates material dissatisfaction and political aspirations that they really feel. At the same time, the new bourgeoisie, realize the economic inefficiencies of command, see that economic changes being blocked by measurable accomplishments praised by Centralized government and can only be achieved through political change and a more extensive participation. However, the budget is not the primary orientation for Tunisia which means that taking over control will not allow the firms to evolve [9].

The internal Tunisian is currently changing to overcome domestic and foreign companies. It includes Indonesian company that is now becoming a reference for Indonesia to perform an intimate diplomacy to Tunisia. The next stage is when a liberalization system that brought a change in the system embraced by Tunisia, then Indonesia will have an excellent opportunity to give more investment to the country.

Susan, also explains the next stage to approach Tunisia is through the State-Firm diplomacy with Tunisia. Indonesia can use PT Medco Energy International as a reference because the company has been working in developing and establishing a partnership between the two countries. Following the establishment of the diplomacy PT Medco Energy International gave the sign that they would return to the country, it was expressed on 19 August 2014 in Movenpick Hotel, Gammarth, Tunisia. This was also done to celebrate the $69^{\text {th }}$ Independence Day of Indonesia. The realization of the partnership can be seen discounted rate given by PT Medco Energy International to the Chinook Energy Inc.

Besides, it can be proved that the role of Indonesia in diplomacy cooperation has been done by the companies from Indonesia to Tunisia. There is a direct investment cooperation that which targetted the government of Tunisia both before and after the Arab Spring. The realization of this action stipulates the new structural change in the economic system of Tunisia. Previously, Tunisia used the command economic system that allowed the state to entirely controlled the dynamic and transaction between the companies both domestically and internationally.

\section{CONCLUSION}

The wealth of Tunisia is a gift; Indonesia also has the same wealth of natural resources in its land. It is a great opportunity to do cooperation between these two countries. Indonesia must immediately do cooperation with Tunisia in the commercial sector. The companies should be the first object in the realization of the cooperation between Indonesia and Tunisia.

Indonesia's condition is beneficial in determining which party to be involved in the cooperation. Diplomacy is the primary way to determine how to perform the cooperation that can be seen from the relationship between domestic companies and the state.

It will be the separate changes in the patterns of cooperation of Indonesia in addressing the moment of the post Arab Spring, which can benefit the country and also the relations between Indonesia and Tunisia. It is a good implication of post Arab Spring in which Indonesia can get the chance improve its development. 


\section{References}

[1] Quandl Tunisia Economy Data accessed 29 Desember 2014 , https://www.quandl.com/c/tunisia/tunisiaeconomy-data.

[2] Susan Strange, States, Firms and Diplomacy Blackwell Publishing on behalf of the Royal Institute of International Affairs, http://www.jstor.org/stable/2620458, pp.2-6

[3] Mondher Ben Ayed The Dynamic Transition in Tunisia and their implications on the economy Legatum Insitute, (London: June 2013), p. 5, published

[4] United Nations Economic Commisions for Africa (Sub regional offfice for North Africa) Tunisia : Economic Situations and outlook in the current transition phase ECA Document, (Ethiopia: 2014), p. 6

[5] Varia,id, Kerjasama Ekonomi Tunisia-Indonesia Tunggu Kepastian Transisi accessed 29 December 2014, http://www.varia.id/2014/12/10/kerja-samaekonomi-tunisia-indonesia-tunggu-kepastian$\underline{\text { transisi }}$

[6] UK Daily Mail Indonesia Press Medco Energi Increase Investment Tunisia Investor Daily accessed 29 December 2014, http://www.dailymail.co.uk/wires/reuters/article2758799/INDONESIA-PRESS-Medco-Energiincrease-investment-Tunisia-Investor-Daily.html

[7] Tribun News Medco Gom Resource Kerja sama kembangkan Migas accessed 29 Desember 2014, http://m.tribunnews.com/bisnis/2013/03/28/medcogom-resources-kerja-sama-kembangkan-migas

[8] See Susan Strange States, Firms and Diplomacy Blackwell Publishing on behalf of the Royal Institute of International Affairs, http://www.jstor.org/stable/2620458, p. 4

[9] See Susan Strange States, Firms and Diplomacy Blackwell Publishing on behalf of the Royal Institute of International Affairs, http://www.jstor.org/stable/2620458, p. 5 